\title{
An Innovative Approach to the Development of Project Management Processes for Small-scale Projects in a large Engineering Company
}

\author{
Claude Y. Laporte \\ École de technologie supérieure \\ Department of Software and IT Engineering \\ 1100 Notre-Dame Street West, Montréal \\ Québec H3C 1K3, Canada, \\ Claude.Y.Laporte@etsmtl.ca
}

\author{
Frédéric Chevalier \\ Tetra Tech \\ Power division \\ 5100 Sherbrooke Street East, Suite 900, \\ Montréal Québec H1V 3R9, Canada, \\ Frederic.Chevalier@tetratech.com
}

Copyright $(0) 2015$ by C. Y. Laporte, F. Chevalier, Permission granted to INCOSE to publish and use.

\begin{abstract}
A Canadian division of a large American engineering company has developed and implemented project management processes for their small-scale and medium-scale projects. The company was already using a robust project management process for their large-scale projects. The objectives of this process improvement project were to reduce cost overruns and project delays, standardize practices to facilitate the integration of new managers, increase the level of customer satisfaction and to reduce risk-related planning deviations. For this improvement project, the engineering organization used the new ISO/IEC 29110 standard developed specifically for very small entities. An analysis of the cost and the benefits of the implementation of small and medium scale project management processes was performed using the ISO economic benefits of standard methodology. The engineering enterprise estimated that, over a three-year timeframe, savings of about $780,000 \$$ would be realized due to the implementation of project management processes using the ISO/IEC 29110 standard.
\end{abstract}

\section{Introduction}

A large majority of enterprises worldwide are very small entities (VSEs). In Europe, for instance, as illustrated in table 1 , over $92 \%$ of enterprises, called micro-enterprises, have up to 9 employees and another 6.5\% have between 10 and 49 employees. Micro enterprises account for $70 \%$ to $90 \%$ of enterprises in Organisation for Economic Co-operation and Development (OECD 2005 ) countries and about $57 \%$ in USA. 


\section{5th Annual INCOSE International Symposium (IS2015) \\ Seattle, July 13-16, 2015}

Table 1: Size of enterprises in Europe (Moll 2013)

\begin{tabular}{|l|r|r|r|r|}
\hline \multicolumn{1}{|c|}{ Type of enterprise } & $\begin{array}{c}\text { Number } \\
\text { of employees }\end{array}$ & $\begin{array}{c}\text { Annual } \\
\text { turnover } \\
\text { (EURO) }\end{array}$ & $\begin{array}{c}\text { Number } \\
\text { of enterprises } \\
\text { (\% of overall) }\end{array}$ & $\begin{array}{c}\text { Number } \\
\text { of enterprises }\end{array}$ \\
\hline Micro-enterprises & $10-49$ & $\leq 2$ million & $92.2 \%$ & 19968000 \\
\hline Small enterprises & $50-249$ & $\leq 50$ million & $1.1 \%$ & 228000 \\
\hline Medium enterprises & 87100000 & & $99.8 \%$ & $21544000 *$ \\
\hline SMEs, total & $>250$ & $>50$ million & & \\
\hline Large enterprises & 42900000 & & $0.2 \%$ & 43000 \\
\hline $\begin{array}{l}\text { Large enterprises, } \\
\text { Total }\end{array}$ & & & \\
\hline * Independent companies only, excluding legally independent companies that are part of large enterprises.
\end{tabular}

Studies and surveys confirmed that most engineering standards did not address the needs of very small entities, especially those with a low capability level (Land 1997, Laporte 2008). Compliance with standards is difficult if not impossible for them to achieve. Subsequently, VSEs have no or very limited ways to be recognized as enterprises that produce quality systems in their domain. Therefore, they are often cut off from some economic activities.

Research showed that VSEs find it difficult to relate ISO standards to their business needs and to justify the application of the standards to their business practices. Most of these VSEs can't afford the resources - in number of employees, cost, and time-or see a net benefit in establishing processes. In 2004, an ISO working group (ISO/IEC JTC1 SC7 ${ }^{1}$ Working Group 24) has been mandated to develop a set of standards and guides to address the issues facing VSEs (Laporte 2013, Laporte 2014a).

This article describes the main activities associated with the development and implementation of project management processes for small and medium scale engineering projects in a Canadian division of a large American engineering company (Chevalier 2012). Even though this organization is considered a large enterprise, a large number of their projects are within the scope of the new ISO/IEC 29110 developed specifically for very small entities, i.e. enterprises, organizations, departments and projects of up to 25 people. We present the business objectives of the improvement project, the approach to select the frameworks used to document the processes, a brief description of the ISO/IEC 29110 standards used to document the project management processes, the methodology used to estimate the cost and benefits of the process documentation activities and a description of the processes and their support tools.

\section{Objectives of the Improvement Project}

The project management process improvement program was targeted at one division of an engineering company, which was created a decade ago and now boasts around 400 employees across 10 offices throughout Canada. As a relatively new entity, it had no efficient tools or

\footnotetext{
${ }^{1}$ International Organization for Standardization/ International Electrotechnical Commission Joint Technical Committee 1/ Sub Committee 7
} 


\section{5th Annual INCOSE International Symposium (IS2015) \\ Seattle, July 13-16, 2015}

project management processes suited to managing small-scale projects. The strong growth of the division in recent years made management aware of the need to improve its methods in order to remain competitive. For this reason, most of the projects managed by this division include project plans and cost-time estimates. In most cases, these projects involve updating or improving existing infrastructures. Hence the challenge of handling multiple small-scale, fastmoving projects allowing little room for unwieldy management processes, but still requiring an efficient and straightforward monitoring process.

The improvement program's objective was to avoid cost overruns and project delays, to standardize practices to facilitate the integration of new managers, to increase the level of customer satisfaction and to reduce risk-related planning deviations.

\section{Managing projects of varying scale}

Projects in one division, of the engineering enterprise, were classified into three categories according to duration, size, number of disciplines involved and engineering fees. It was decided to classify the engineering projects into three categories: small-, medium- and large-scale projects (see table 2). As illustrated in table 2, over $95 \%$ of the projects fall in the small- and medium-scale categories.

Table 2: Classification of the division's projects (in Canadian Dollar)

\begin{tabular}{|l|l|l|l|}
\hline & \multicolumn{1}{|c|}{ Small project } & \multicolumn{1}{c|}{ Medium project } & \multicolumn{1}{c|}{ Large project } \\
\hline Duration of project & Less than 2 months & $\begin{array}{l}\text { Between } 2 \text { and } 8 \\
\text { months }\end{array}$ & More than 8 months \\
\hline Size of team & Up to 4 people & $\begin{array}{l}\text { Between } 4 \text { and } 8 \\
\text { people }\end{array}$ & More than 8 people \\
\hline $\begin{array}{l}\text { Number of } \\
\text { engineering } \\
\text { specialties involved }\end{array}$ & One & More than one & Many \\
\hline Engineering fees & $\begin{array}{l}\text { Between } \$ 5,000 \text { and } \\
\$ 70,000\end{array}$ & $\begin{array}{l}\text { Between } \$ 50,000 \text { and } \\
\$ 350,000\end{array}$ & Over $\$ 350,000$ \\
\hline $\begin{array}{l}\text { Percentage of } \\
\text { projects }\end{array}$ & $70 \%$ & $25 \%$ & $5 \%$ \\
\hline
\end{tabular}

The goal-problem approach (Potter, 2002) was used to set the improvement program's priorities and to ensure that the goals set by the program addressed tangible problems that the company wished to solve. This approach includes the following steps:

- Determine the business goals (see table 3) and the problems that the company wishes to solve

- Group goals and problems

- Prioritize problems

- Develop and implement an action plan 


\section{5th Annual INCOSE International Symposium (IS2015) \\ Seattle, July 13-16, 2015}

Table 3: Division's business goals

\begin{tabular}{|c|c|}
\hline $\begin{array}{l}\text { Objective } \\
\text { ID }\end{array}$ & Description \\
\hline $\mathrm{O}-1$ & Facilitate the integration of new project managers. \\
\hline $\mathrm{O}-2$ & Achieve a global customer satisfaction level of $80 \%$. \\
\hline $\mathrm{O}-3$ & $\begin{array}{l}\text { Meet the deadlines and costs planned for the projects, within a } \\
\text { margin of } 5 \% \text {. }\end{array}$ \\
\hline $\mathrm{O}-4$ & Reduce resource overload by $10 \%$ \\
\hline $0-5$ & $\begin{array}{l}\text { Reduce time delays to one week and cost overruns to } 5 \% \text { of the } \\
\text { initial budget. }\end{array}$ \\
\hline $0-6$ & Reduce corrective work during the quality control phase by $10 \%$. \\
\hline O-7 & Reduce non-chargeable time for resources by $10 \%$. \\
\hline
\end{tabular}

Table 4 presents a list of a few problems, ranging from estimation problems to lack of defined practices, that slow down the achievement of the 7 business objectives listed in above.

Table 4: Problems that slow down the achievement of business objectives

\begin{tabular}{|c|l|}
\hline $\begin{array}{c}\text { Problem } \\
\text { ID }\end{array}$ & \multicolumn{1}{c|}{ Description } \\
\hline P-1 & Difficulty in integrating new project managers \\
\hline P-2 & Lack of knowledge of existing tools \\
\hline P-3 & $\begin{array}{l}\text { Difficulty faced by new project managers to understand the ways of } \\
\text { doing business of the division }\end{array}$ \\
\hline P-4 & Projects in difficulty due to poor time management \\
\hline P-5 & Projects in difficulty due to poor management of resources \\
\hline
\end{tabular}

Managers grouped the problems relative to the 7 goals. Finally, they estimated the expected cost and benefit of each objective in order to prioritize them and group them in different implementation phases. Table 5 shows an example of the prioritization of one business objective.

Table 5: Example of a prioritization of an objective

\begin{tabular}{|c|l|c|c|c|}
\hline \multicolumn{5}{|c|}{ Priorization of Objectives } \\
\hline $\begin{array}{c}\text { Objective } \\
\text { ID }\end{array}$ & $\begin{array}{c}\text { Estimated } \\
\text { Benefits } \\
{[1-10]}\end{array}$ & $\begin{array}{c}\text { Estimate } \\
\text { d Cost } \\
{[1-10]}\end{array}$ & $\begin{array}{c}\text { Priority } \\
\text { (Benefits/Cost) }\end{array}$ \\
\hline O-1 & $\begin{array}{l}\text { Facilitate the } \\
\text { integration of new } \\
\text { project managers. }\end{array}$ & 5 & 10 & 0.50 \\
\hline
\end{tabular}

As the last activity of this objective setting phase, a risk management plan was developed in order to prevent - i.e., reduce the probability and minimize the impact of - certain events on the project process. 


\section{5th Annual INCOSE International Symposium (IS2015) \\ Seattle, July 13-16, 2015}

\section{Selection and Evaluation of Improvement Frameworks}

There are several frameworks which describes recognized project management practices, such as the Guide to the Project Management Body of Knowledge (PMBOK ${ }^{\circledR}$ Guide) published by the Project Management Institute (PMI 2013); maturity models such as the Capability Maturity Model Integration $\left(\mathrm{CMMI}^{\circledR}\right)$ for Development of the Software Engineering Institute (SEI 2010); and standards such as the new ISO/IEC 29110 series for very small entities (ISO 2011).

A meeting with the improvement program sponsors helped define a set of criteria to determine the most suitable project management framework for the engineering division. The following criteria were selected:

- The framework is suitable for the management of small-scale projects (small team and limited means),

- The company's management knows the framework,

- The framework is recognized by the company's customers,

- Tools are available to facilitate the use of the framework,

- The framework may easily be used and integrated into the existing processes,

- A recognition mechanism through accreditation for the company is available,

- The framework is readily available

Before analyzing the selected frameworks, each criterion was weighted by its importance according by the project sponsors. Table 6 describes the 7 criterion used to evaluate the frameworks as well as the justification for the weight assigned to each criterion.

Table 6: Weights of the criterion used to evaluate the frameworks

\begin{tabular}{|l|c|l|}
\hline $\begin{array}{c}\text { Description of } \\
\text { the Criteria }\end{array}$ & $\begin{array}{c}\text { Weight assigned } \\
\text { to each criteria } \\
(1=\text { Low } \\
\text { importance to } 3= \\
\text { High importance })\end{array}$ & Justification \\
\hline $\begin{array}{l}\text { Adapted for the } \\
\text { management of } \\
\text { small projects }\end{array}$ & 3 & $\begin{array}{l}\text { The majority of projects are small projects. } \\
\text { A complex method will need to be adapted to small } \\
\text { and medium scale projects to be effective. } \\
\text { Using standards already adapted to small projects } \\
\text { could reduce the effort required for the } \\
\text { development of small and medium scale project } \\
\text { processes }\end{array}$ \\
\hline $\begin{array}{l}\text { Known to the } \\
\text { management of } \\
\text { the } \\
\text { organization }\end{array}$ & 2 & $\begin{array}{l}\text { Using a known framework could promote the } \\
\text { commitment of management to solutions that will } \\
\text { be developed. }\end{array}$ \\
\hline $\begin{array}{l}\text { Recognized by } \\
\text { the company's } \\
\text { customers }\end{array}$ & 2 & $\begin{array}{l}\text { Some customers have project management } \\
\text { practices based on standards. } \\
\text { The use of similar frameworks could facilitate } \\
\text { communication and the monitoring of projects with } \\
\text { customers }\end{array}$ \\
\hline
\end{tabular}




\section{5th Annual INCOSE International Symposium (IS2015) \\ Seattle, July 13-16, 2015}

\begin{tabular}{|l|l|l|}
\hline $\begin{array}{l}\text { Tools to } \\
\text { facilitate the } \\
\text { use of } \\
\text { standards are } \\
\text { available }\end{array}$ & 2 & $\begin{array}{l}\text { - Using standards supported with tools could reduce } \\
\text { the effort for the development of processes }\end{array}$ \\
\hline $\begin{array}{l}\text { Ease of } \\
\text { integration with } \\
\text { existing } \\
\text { organizational } \\
\text { processes }\end{array}$ & 3 & $\begin{array}{l}\text { It is very important that the standards can be used } \\
\text { in the current business context. } \\
\text { Existing processes are not under the responsibility } \\
\text { of the Division and therefore cannot be changed } \\
\text { easily. } \\
\text { Changes made in the Division should not force } \\
\text { changing the practices employed by other } \\
\text { divisions. }\end{array}$ \\
\hline $\begin{array}{l}\text { Accreditation/ } \\
\text { Certification } \\
\text { available }\end{array}$ & 1 & $\begin{array}{l}\text { The company does not currently show interest for } \\
\text { accreditation related to project management } \\
\text { practices. }\end{array}$ \\
\hline $\begin{array}{l}\text { Ease of access } \\
\text { to frameworks }\end{array}$ & 1 & $\begin{array}{l}\text { The company has the monetary means to acquire } \\
\text { the frameworks. } \\
\text { The impact of this criterion is small. }\end{array}$ \\
\hline
\end{tabular}

The sponsors evaluated the 5 selected frameworks using the weighted selection criteria. Table 7 illustrates the evaluation of the frameworks selected. The final score for each framework is obtained by multiplying each individual score by the weight of each criterion and the by adding the individual scores. As illustrated in table 7, the PMBOK ${ }^{\circledR}$ Guide and the ISO/IEC 29110 obtained the highest overall score.

Table 7: Evaluation of the frameworks selected

\begin{tabular}{|c|c|c|c|c|c|c|c|c|}
\hline \multirow[b]{3}{*}{ Framework } & \multicolumn{8}{|c|}{ Evaluation criteria } \\
\hline & \multicolumn{2}{|c|}{$\begin{array}{l}\text { Adapted for the } \\
\text { management of s mall } \\
\text { projects }\end{array}$} & \multicolumn{2}{|c|}{$\begin{array}{l}\text { Known to the } \\
\text { management of the } \\
\text { organization }\end{array}$} & \multicolumn{2}{|c|}{$\begin{array}{l}\text { Recognized by the } \\
\text { company's cus tomers }\end{array}$} & \multicolumn{2}{|c|}{$\begin{array}{c}\text { Tools to facilitate the } \\
\text { use of s tandards are } \\
\text { available }\end{array}$} \\
\hline & $\begin{array}{c}\text { Weight } \\
\text { as signed to } \\
\text { each criteria }\end{array}$ & $\begin{array}{c}\text { Evaluation } \\
\text { of } \\
\text { framework } \\
\text { using } \\
\text { criteria }\end{array}$ & $\begin{array}{c}\text { Weight } \\
\text { as signed to } \\
\text { each criteria }\end{array}$ & $\begin{array}{c}\text { Evaluation of } \\
\text { framework } \\
\text { using } \\
\text { criteria }\end{array}$ & $\begin{array}{c}\text { Weight } \\
\text { as signed to } \\
\text { each criteria }\end{array}$ & $\begin{array}{c}\text { Evaluation of } \\
\text { framework } \\
\text { using } \\
\text { criteria }\end{array}$ & $\begin{array}{c}\text { Weight } \\
\text { as signed to } \\
\text { each criteria }\end{array}$ & $\begin{array}{c}\text { Evaluation of } \\
\text { framework } \\
\text { using } \\
\text { criteria }\end{array}$ \\
\hline CMMI-DEV, version 1.3 & 3 & 1 & 2 & 1 & 2 & 0 & 2 & 2 \\
\hline CMMI-SVC, version 1.3 & 3 & 1 & 2 & 0 & 2 & 0 & 2 & 2 \\
\hline PMBOK Guide (PMI) & 3 & 1 & 2 & 3 & 2 & 3 & 2 & 2 \\
\hline PRINCE2 2009 Edition & 3 & 1 & 2 & 0 & 2 & 0 & 2 & 2 \\
\hline ISO/IEC 29110 & 3 & 3 & 2 & 0 & 2 & 0 & 2 & 3 \\
\hline
\end{tabular}

\begin{tabular}{|c|c|c|c|c|c|c|c|}
\hline \multirow[b]{3}{*}{ Framework } & \multicolumn{6}{|c|}{ Evaluation criteria } & \\
\hline & \multicolumn{2}{|c|}{$\begin{array}{c}\text { Ease of integration } \\
\text { with exis ting } \\
\text { organizational } \\
\text { processes }\end{array}$} & \multicolumn{2}{|c|}{$\begin{array}{c}\text { Accre ditation/Ce rtificati } \\
\text { on available }\end{array}$} & \multicolumn{2}{|c|}{$\begin{array}{l}\text { Ease of access to } \\
\text { documents }\end{array}$} & \\
\hline & $\begin{array}{c}\text { Weight } \\
\text { as signed to } \\
\text { each criteria }\end{array}$ & $\begin{array}{c}\text { Evaluation } \\
\text { of } \\
\text { framework } \\
\text { using } \\
\text { criteria } \\
\end{array}$ & $\begin{array}{c}\text { Weight } \\
\text { as signed to } \\
\text { each criteria }\end{array}$ & $\begin{array}{c}\text { Evaluation of } \\
\text { framework } \\
\text { using } \\
\text { criteria }\end{array}$ & $\begin{array}{c}\text { Weight } \\
\text { as signed to } \\
\text { each criteria }\end{array}$ & $\begin{array}{c}\text { Evaluation of } \\
\text { framework } \\
\text { using } \\
\text { criteria }\end{array}$ & Total Score \\
\hline CMMI-DEV, version 1.3 & 3 & 1 & 1 & 3 & 1 & 3 & 18 \\
\hline CMMI-SVC, version 1.3 & 3 & 1 & 1 & 3 & 1 & 3 & 16 \\
\hline PMBOK Guide (PMI) & 3 & 3 & 1 & 0 & 1 & 3 & 31 \\
\hline PRINCE2 2009 Edition & 3 & 1 & 1 & 2 & 1 & 1 & 13 \\
\hline ISO/IEC 29110 & 3 & 3 & 1 & 2 & 1 & 3 & 29 \\
\hline
\end{tabular}




\section{5th Annual INCOSE International Symposium (IS2015) \\ Seattle, July 13-16, 2015}

Table 8 describes the frameworks evaluated, the cumulative score of each framework evaluated as well as the justifications for each score and the decisions (e.g. select, discard) about each of them.

Table 8: Analysis and justification of the five frameworks

\begin{tabular}{|c|c|c|c|}
\hline $\begin{array}{l}\text { Frameworks } \\
\text { Evaluated }\end{array}$ & $\begin{array}{c}\text { Cumulative } \\
\text { Result }\end{array}$ & $\begin{array}{c}\text { Decision about a } \\
\text { framework }\end{array}$ & Justification \\
\hline $\begin{array}{c}\text { CMMI-DEV, V1.3, } \\
2010\end{array}$ & 18 & Not selected & $\begin{array}{l}\text { - This document is not well known by the } \\
\text { management of the company and its customers. } \\
\text { - Sponsors of the improvement project showed } \\
\text { little interest in this document. }\end{array}$ \\
\hline $\begin{array}{c}\text { CMMI-SVC, V1.3, } \\
2010\end{array}$ & 16 & Not selected & $\begin{array}{l}\text { - This document is not well known by the } \\
\text { management of the company and its customers. } \\
\text { - Sponsors of the improvement project showed } \\
\text { little interest in this document. }\end{array}$ \\
\hline $\begin{array}{c}\text { PMBOK }^{\circledR} \text { Guide } \\
\text { 4th edition }\end{array}$ & 31 & $\begin{array}{l}\text { Selected for the } \\
\text { large-scale projects }\end{array}$ & $\begin{array}{l}\text { It is a known document of the management of } \\
\text { the company and its customers. } \\
\text { - Sponsors of the improvement project have } \\
\text { expressed interest in this document. } \\
\text { This framework is not specifically designed for } \\
\text { small projects. It will be used only to complete } \\
\text { the documentation for the large-scale projects } \\
\text { process }\end{array}$ \\
\hline $\begin{array}{l}\text { PRINCE2 } 2^{\circledR}, 2009 \\
\quad \text { edition }\end{array}$ & 13 & Not selected & $\begin{array}{l}\text { - It is a repository little used in Canada. } \\
\text { - Sponsors of the improvement project have little } \\
\text { interest in this repository. }\end{array}$ \\
\hline ISO/IEC 29110 & 29 & $\begin{array}{l}\text { Selected for } \\
\text { documenting the } \\
\text { process of small } \\
\text { projects and } \\
\text { medium-scale } \\
\text { projects }\end{array}$ & $\begin{array}{l}\text { It is an unknown repository from management } \\
\text { of the company and its customers. } \\
\text { This framework is specially designed for small } \\
\text { projects. } \\
\text { - } \begin{array}{l}\text { However, the concepts of project management } \\
\text { of this repository are in line with those } \\
\text { described in the PMBOK Guide. } \\
\text { This framework will be used for the } \\
\text { development of project management processes } \\
\text { for small and medium scale projects. }\end{array}\end{array}$ \\
\hline
\end{tabular}

The ISO/IEC 29110 was the framework selected for the improvement project. Even if the company's division comprises more than 400 employees, a significant number of small-scale projects are carried out by small teams. Since the ISO/IEC 29110 standards applies to Very Small Entities (VSEs), i.e. enterprises, organizations, departments and projects of up to 25 people, this standard was very suitable for the engineering division of the company.

\section{Overview of the Basic profile of ISO/IEC 29110}

Many international standards have been developed to capture proven management and engineering practices. However, these standards were not written for very small organizations and were consequently difficult to apply in such settings. An ISO Working Group has been 


\section{5th Annual INCOSE International Symposium (IS2015) \\ Seattle, July 13-16, 2015}

established to address these difficulties (ISO 2005). The working group mandated to develop ISO/IEC 29110 conducted, in 9 languages, an international survey of small and very small organizations to question them about their use of standards as well as to collect data to identify problems and potential solutions to help them apply standards. Over $62 \%$ of the responses, received from 32 countries, indicated they would like more guidance with examples, and 55\% were asking for lightweight and easy-to-understand standards, complete with templates. Finally, the respondents have indicated that it had to be possible to implement standards with minimum cost, time, and resources (Laporte 2012).

The ISO working group decided to develop a set of 4 profiles, i.e. a four-stage road map (Entry, Basic, Intermediate, Advanced) providing a progressive approach to satisfying the needs and expectations of a vast majority of VSEs. VSEs targeted by the Entry Profile are VSEs working on small projects (e.g. at most six person-months effort) and for start-up VSEs (ISO 2012). The Basic profile describes development practices of a single application by a single project team of a VSE (ISO 2011). The Intermediate Profile is targeted at VSEs developing more than one project with more than one team. The Advanced Profile is targeted to VSEs which want to sustain and grow as an independent competitive development business.

For illustration purposes, we will briefly describe the profile used, i.e. the Basic profile, to develop the medium-scale project management process of the engineering organization. At the time that the project management improvement program was launched, only the software Entry and Basic profiles had been published by ISO. The ISO/IEC 29110 systems engineering profiles were published after this improvement project had been completed. Even though, as illustrated in figure 1, the Entry and Basic profiles are composed of a project management (PM) process and a software implementation (SI) process, only the project management processes were used to develop the small-scale and medium-scale project management processes of the engineering organization.

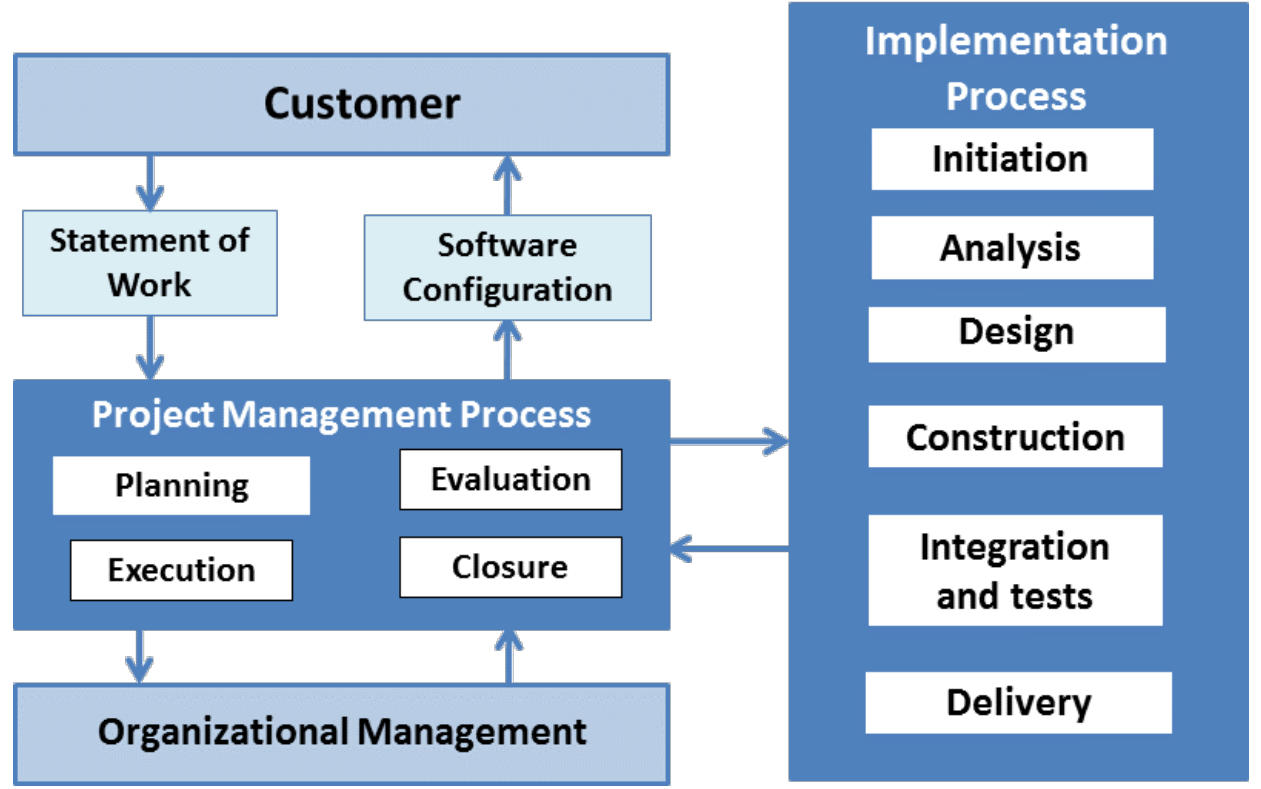

Figure 1. ISO/IEC 29110 Basic profile processes and activities (Laporte 2014b) 


\section{5th Annual INCOSE International Symposium (IS2015) \\ Seattle, July 13-16, 2015}

As illustrated in figure 1, the customer's Statement of Work (SOW) is used to initiate the PM process. The project plan will be used to guide the development of the software. The PM process closure activity will deliver a Software Configuration (i.e. product and documentation) and will obtain the customer's acceptance to formalize the end of the project.

The purpose of the PM process is to establish and carry out in a systematic way the tasks of the project in order to meet the objectives in the expected quality, time and costs. Table 9 describes the seven objectives of PM process of the Basic profile. These objectives have been identified to meet the needs and characteristics of VSEs that are executing one project at a time.

Table 9: Objectives of the project management process of the Basic profile (ISO 2011) PM.O1. The Project Plan for the execution of the project is developed according to the Statement of Work and reviewed and accepted by the Customer. The tasks and resources necessary to complete the work are sized and estimated.

PM.O2. Progress of the project is monitored against the Project Plan and recorded in the Progress Status Record.

PM.O3. The Change Requests are addressed through their reception and analysis. Changes to software requirements are evaluated for cost, schedule and technical impact.

PM.O4. Review meetings with the Work Team and the Customer are held. Agreements are registered and tracked.

PM.O5. Risks are identified as they develop and during the conduct of the project.

PM.O6. A software Version Control Strategy is developed. Items of Software Configuration are identified, defined and baselined.

Modifications and releases of the items are controlled and made available to the Customer and Work Team including the storage, handling and delivery of the items.

PM.O7. Software Quality Assurance is performed to provide assurance that work products and processes comply with the Project Plan and Requirements Specification.

During the project planning activity, a project plan is developed. Then, the assessment and control tasks are used to assess the project's progress against the project plan. Action is then taken, if needed, to eliminate deviations from the project plan or to incorporate changes to the plan. The project closure activity groups together the deliverables produced by the implementation process, such as the software or the user manual, and gets the customer's written acceptance to finalize the project. A repository is established to save the work products and to control their versions during the project.

Figure 2 illustrates the 4 activities of the PM process as well as their input and output products. Each activity is composed of a set of tasks. The task description doesn't impose any technique or method to perform it. Even though figure 2 describes the PM process in a waterfall or sequential 


\section{5th Annual INCOSE International Symposium (IS2015) \\ Seattle, July 13-16, 2015}

approach, ISO/IEC 29110 is not intended to preclude the use of different lifecycles such as iterative, incremental, evolutionary or agile.

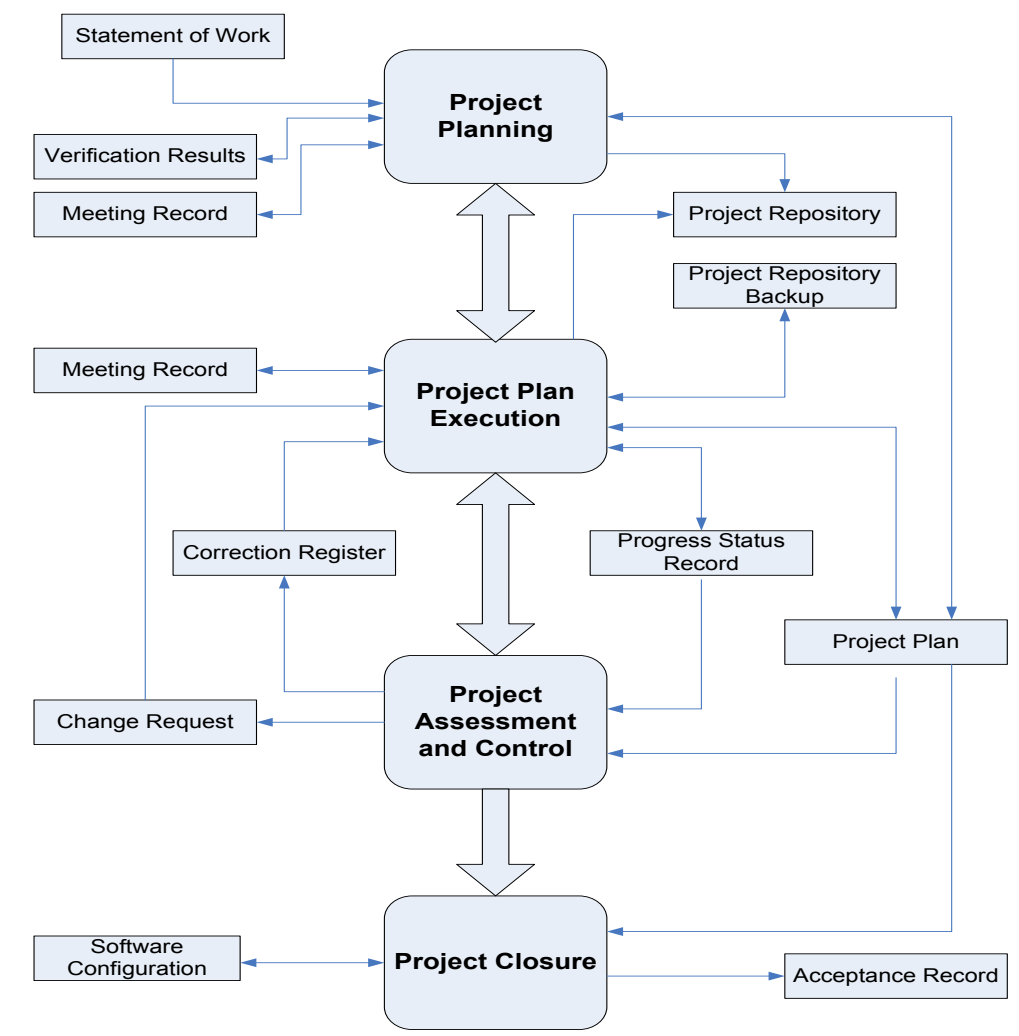

Figure 2. Project management process diagram for software (ISO 2011)

For illustration purposes, one task of the Project Planning activity is described in Table 10. On the left side of the table are listed the roles involved in a task: the project Manager (PM) and the Customer (CUS).

Table 10: Example of a task of the project planning activity (ISO 2011)

\begin{tabular}{|c|c|c|c|}
\hline Role & Task List & Input Products & Output Products \\
\hline $\begin{array}{l}\text { PM } \\
\text { CUS }\end{array}$ & $\begin{array}{l}\text { PM.1.2 Define with the Customer the } \\
\text { Delivery Instructions of each one of the } \\
\text { Deliverables specified in the Statement of } \\
\text { Work. }\end{array}$ & $\begin{array}{l}\text { Statement of Work } \\
\text { [reviewed] }\end{array}$ & \begin{tabular}{|l|} 
Project Plan \\
- Delivery \\
Instructions
\end{tabular} \\
\hline
\end{tabular}

The customer is also involved, during the execution of the project, when he submits change requests, during project review meetings, for the validation and approval of the requirements specifications and for the acceptance of the deliverables. 


\section{5th Annual INCOSE International Symposium (IS2015) \\ Seattle, July 13-16, 2015}

\section{Management process of the engineering organization}

The project management practices used by the engineering division's project managers were assessed against the ISO/IEC 29110 Basic and Entry profiles by interviewing project managers.

Figure 3 shows the overall results of the assessment of the activities of the PM process of the Basic profile. The figure displays the percentage of the tasks performed for each of the following activities of the ISO/IEC 29110 management and engineering guide (ISO 2011):

- Project planning (15 tasks)

- Project plan execution (6 tasks)

- Project assessment and control (3 tasks)

- Project closure (2 tasks)

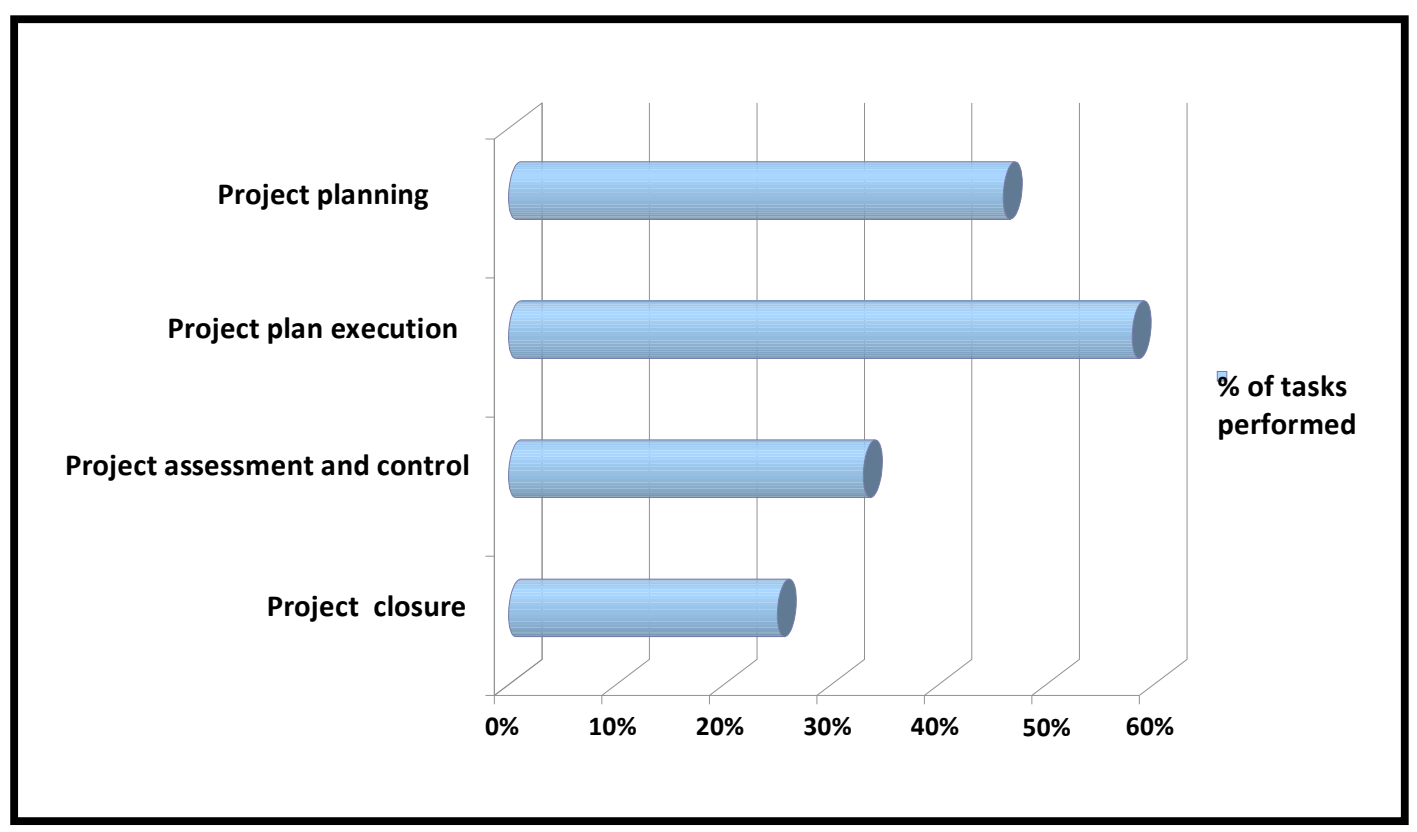

Figure 3. Performance assessment of the Basic profile

We note that a low level of implementation of ISO/IEC 29110 activities was achieved, for medium scale projects, within the engineering company at the beginning of the improvement program. Also, during the interview with managers, it was noted the PM tasks were not performed systematically. In addition, the assessment revealed that PM practices varied from project manager to project manager and that no guideline had been defined for a few tasks. A similar assessment, against the Entry profile, was also carried out for the small-scale projects.

\section{Development of the Project Management Processes}

The development of processes and tools, such as checklists, templates and forms, was the central element of the solution to the problems identified. Discussions with project managers of the organization revealed that they were often burdened with technical tasks in addition to the management of their project. This situation often impacted their ability to perform management tasks despite their level of expertise in project. It was therefore decided that a few checklists might provide a useful tool for project managers for the following reasons: 


\section{5th Annual INCOSE International Symposium (IS2015) \\ Seattle, July 13-16, 2015}

- They are a good way to explain or briefly summarize the tasks to be performed by the project manager

- They help identify quickly the forms and templates available to perform the project management tasks

- They provide quick links to additional references

- The provide guidance to the project manager for storing the project management documents

- They provide an easy means of assessing the implementation of processes

Within the scope of this program to improve project management practices, the following five checklists were developed:

- Small-project management process

- Medium-project management process

- Major-project management process

- Drafting of service proposals

- Detailed project planning

Pilot projects were carried out to test the solutions developed. Testing the solutions in the context of a real-life project helped verify that the proposed solutions were consistent, achievable and comprehensive. It was also noted, when executing the pilot projects, that project managers would appreciate examples of how to implement the tools.

\section{Estimation of the cost and benefits of implementing ISO/IEC 29110}

ISO has developed the "ISO Methodology to assess and communicate the economic benefits of standards". The key objectives of this methodology are to provide (ISO 2010):

- A set of methods that measure the impact of standards on organizational value creation

- Decision makers with clear and manageable criteria to assess the value associated with using standards

- Guidance on developing studies to assess the benefits of standards within a particular industry sector

The approach used by the engineering division, to estimate the cost and benefits, comprised four steps:

- Understanding the company's value chain

- Analyzing the value drivers

- Determining the impacts of standards

- Assessing and consolidating results

The four steps of the ISO methodology are described below.

\section{Step 1: Understanding the company's value chain}

The "value chain" is a concept described by Porter (Porter 2008). Porter describes the value chain as a tool to understand the competitive advantage that a company can have in the actions it 


\section{5th Annual INCOSE International Symposium (IS2015) \\ Seattle, July 13-16, 2015}

undertakes. The value chain is a representation of the different steps for an organization to create value in the form of goods or services to customers.

The performance of an activity can have an impact on cost and create a differentiation from competitors. Hence the advantage of using this tool to determine the impact of the project management improvement project to improve project management practices of the engineering division. Figure 4 illustrates the value chain of the company according to Porter's model.

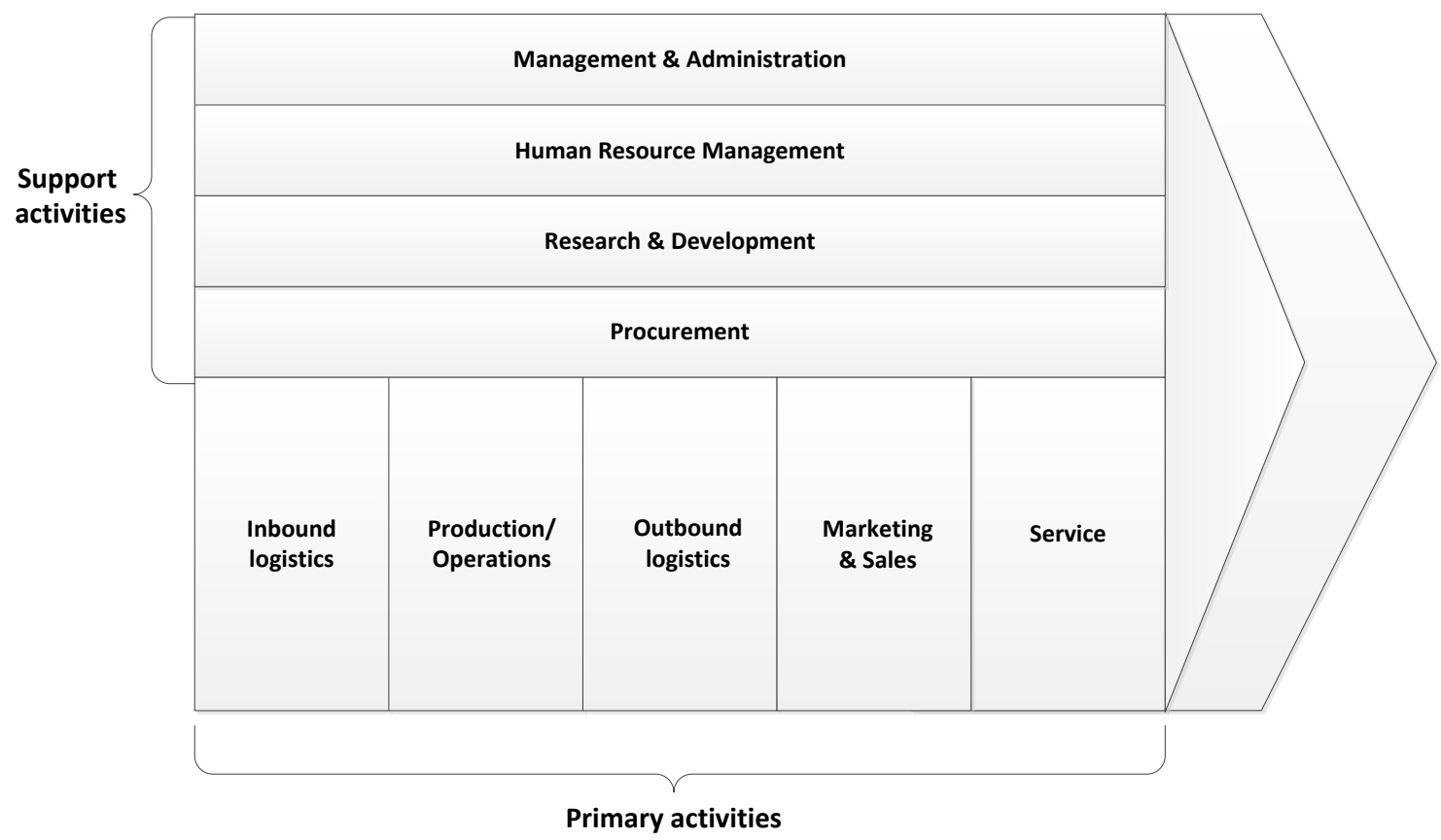

Figure 4. Value chain of the engineering division (adapted from ISO 2010)

In this model, the competence domains of an engineering division of the company are:

- Operations;

○ detailed engineering including the design of plans and specifications;

$\circ$ engineering linked to the achievement of specialized studies.

- Marketing and sales;

O activities related to business development;

○ the development of contractual agreements;

o assessment of services.

- Service

○ activities related to procurement of construction and installation phases of a project;

- monitoring of construction and implementation activities;

$\circ$ activities related to the management of strategic assets.

○ 


\section{Step 2: Analyzing the value drivers}

After discussing with the company's governance board, the elements shown in table 11 were identified as the main value drivers for the engineering consulting firm. The importance (i.e. important (3), largely important (2), very important (1)) of each driver was also determined.

Table 11: Table of value drivers

\begin{tabular}{|c|c|c|c|}
\hline Value driver & Description & Performance indicators & Importance \\
\hline $\begin{array}{l}\text { Quality of the } \\
\text { design process }\end{array}$ & $\begin{array}{l}\text { Quality in terms of } \\
\text { execution time, costs } \\
\text { and quality of } \\
\text { deliverables }\end{array}$ & $\begin{array}{l}\text { Time spent on corrective } \\
\text { engineering work. } \\
\text { Cost overruns related to } \\
\text { quality control. }\end{array}$ & $\begin{array}{l}\text { Very important } \\
\text { (company viability) }\end{array}$ \\
\hline $\begin{array}{l}\text { Efficiency versus } \\
\text { costs }\end{array}$ & $\begin{array}{l}\text { Ability to complete } \\
\text { the work at minimum } \\
\text { cost }\end{array}$ & $\begin{array}{l}\text { Meeting budgets allocated } \\
\text { to each sub-project. } \\
\text { Meeting overall project } \\
\text { budget. }\end{array}$ & $\begin{array}{l}\text { Very important } \\
\text { (company viability) }\end{array}$ \\
\hline $\begin{array}{l}\text { Project } \\
\text { management } \\
\text { capacity }\end{array}$ & $\begin{array}{l}\text { Capacity to manage } \\
\text { projects according to } \\
\text { plans }\end{array}$ & $\begin{array}{l}\text { Cost Performance Index } \\
(\mathrm{CPI})\end{array}$ & $\begin{array}{l}\text { Very important } \\
\text { (completing projects } \\
\text { is the company's } \\
\text { core activity) }\end{array}$ \\
\hline Technical expertise & $\begin{array}{l}\text { Ability to solve } \\
\text { complex problems }\end{array}$ & $\begin{array}{l}\text { Schedule Performance } \\
\text { Index (SPI) }\end{array}$ & Important \\
\hline $\begin{array}{l}\text { Geographic } \\
\text { positioning }\end{array}$ & $\begin{array}{l}\text { Geographic proximity } \\
\text { of customers }\end{array}$ & $\begin{array}{l}\text { Resource usage time (e.g. } \\
\text { overtime) }\end{array}$ & Average importance \\
\hline Partnership & $\begin{array}{l}\text { Capacity to initiate } \\
\text { partnerships with } \\
\text { other companies }\end{array}$ & $\begin{array}{l}\text { Number of partnerships } \\
\text { Recurring customers }\end{array}$ & Average importance \\
\hline Flexibility & $\begin{array}{l}\text { Capacity to adapt to } \\
\text { different customer } \\
\text { needs }\end{array}$ & $\begin{array}{l}\text { Number of services } \\
\text { provided } \\
\text { Type of service compared } \\
\text { with competitors }\end{array}$ & Important \\
\hline
\end{tabular}

\section{Step 3: Determining the Impacts of Standards}

The objective of this step was to identify the significant impacts that the improvement project will have on the company. Impacts were selected from the "Standards Impact Map" of the ISO methodology. Table 12 illustrates a subset of the impacts for the production category, similar tables were also developed for marketing and service categories. The links between the impacts of standards and the performance indicators identified in the previous step are also presented.

Table 12: Subset of Impacts of standard

\begin{tabular}{|c|c|c|c|c|c|}
\hline Category & $\begin{array}{c}\text { Impact } \\
\text { ID }\end{array}$ & $\begin{array}{c}\text { Impact } \\
\text { Title }\end{array}$ & Description & $\begin{array}{c}\text { Priority } \\
{[1-h i g h,} \\
3-l o w]\end{array}$ & $\begin{array}{c}\text { Performance } \\
\text { Indicator }\end{array}$ \\
\hline
\end{tabular}




\begin{tabular}{|c|c|c|c|c|c|}
\hline \multirow[t]{3}{*}{$\begin{array}{l}\text { Production/ } \\
\text { Operation }\end{array}$} & P-1 & $\begin{array}{l}\text { Improvement } \\
\text { of internal } \\
\text { information } \\
\text { transfer }\end{array}$ & $\begin{array}{l}\text { The use of } \\
\text { standardized } \\
\text { documents and } \\
\text { specifications } \\
\text { allows a more } \\
\text { efficient } \\
\text { transfer of } \\
\text { information } \\
\text { internally }\end{array}$ & 2 & 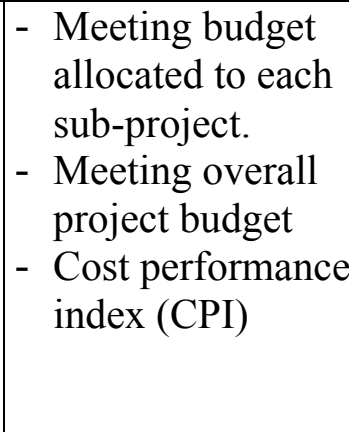 \\
\hline & P-2 & $\begin{array}{l}\text { Better } \\
\text { training of } \\
\text { staff }\end{array}$ & $\begin{array}{l}\text { Staff can be } \\
\text { better trained } \\
\text { due to the } \\
\text { standardization } \\
\text { of processes }\end{array}$ & 3 & $\begin{array}{l}\text { - Meeting budget } \\
\text { allocated to each } \\
\text { sub-project. } \\
\text { - Meeting overall } \\
\text { project budget } \\
\text { - Cost performance } \\
\text { index (CPI) }\end{array}$ \\
\hline & P-3 & $\begin{array}{l}\text { Additional } \\
\text { cost of staff }\end{array}$ & $\begin{array}{l}\text { Increased costs } \\
\text { due to the } \\
\text { implementatio } \\
n \text { of processes }\end{array}$ & 1 & $\begin{array}{l}\text { - Cost of the } \\
\text { process } \\
\text { improvement } \\
\text { project }\end{array}$ \\
\hline
\end{tabular}

\section{Step 4: Assessing and Consolidating Results}

During this final step, two persons of the enterprise determined the impacts separately: the engineer responsible for the improvement project and his supervisor. Table 13 illustrates the financial impacts due to the use of standardized documents and specifications on the internal transfer of information.

Table 13: Assessment of the financial impacts about the improvement of internal information transfer

\begin{tabular}{|c|c|c|c|c|}
\hline Impact ID & \multicolumn{2}{|c|}{ Description of Impacts } & $\begin{array}{c}\text { Evaluator } \\
\quad \# 1\end{array}$ & $\begin{array}{l}\text { Evaluator } \\
\quad \# 2\end{array}$ \\
\hline Production & \multicolumn{2}{|c|}{ Improvement of internal information transfer } & & \\
\hline & $\begin{array}{l}\text { What is the overall cost overrun } \\
\text { of projects? }\end{array}$ & $\begin{array}{l}\text { Estimation based } \\
\text { on the } \\
\text { Profitability } \\
\text { Report }\end{array}$ & $555,500 \$$ & $555,500 \$$ \\
\hline & $\begin{array}{l}\text { What percentage of the project } \\
\text { was in trouble due to a problem } \\
\text { of information transfer? }\end{array}$ & & $25 \%$ & $20 \%$ \\
\hline & $\begin{array}{l}\text { How much does the project } \\
\text { management process can } \\
\text { improve the transfer of } \\
\text { information? }\end{array}$ & & $80 \%$ & $75 \%$ \\
\hline & & Financial impact & $111,100 \$$ & $83,325 \$$ \\
\hline
\end{tabular}




\section{5th Annual INCOSE International Symposium (IS2015) \\ Seattle, July 13-16, 2015}

The improvement program project sponsors did an estimate of anticipated costs and benefits over a period of three years over the other 5 dimensions: better staff training, additional cost of staff, better quality of deliverables, better management of quality and more effective internal standardization. Table 14 shows the results of the 6 dimensions for the first three years of the project management process implementation.

Table 14: Anticipated costs and benefits from the improvement program (\$CAD)

\begin{tabular}{|l|c|c|c|c|}
\hline & Year 1 & Year 2 & Year 3 & Total \\
\hline $\begin{array}{l}\text { Implementation } \\
\text { and maintenance } \\
\text { costs }\end{array}$ & $59,600 \$$ & $50,100 \$$ & $50,100 \$$ & $159,800 \$$ \\
\hline Net benefits & $255,500 \$$ & $265,000 \$$ & $265,000 \$$ & $785,500 \$$ \\
\hline
\end{tabular}

\section{Development of the processes and support tools}

Once the impacts have been estimated, the solutions (e.g. processes, forms, templates and checklists) have been developed taking into account the type of company projects. A significant portion of projects undertaken by the company, about $70 \%$, are small-scale projects with a typical duration of less than four months with a team of less than five people. These small-scale projects have the following constraints:

- The completion dates are often too short to set-up a complex project management structure,

- The number of projects executed in parallel has a significant impact on the human resources assigned to them,

- Some project managers do not necessarily have all the required project management knowledge. They are very technically competent individuals who are assigned management tasks. But, they have to perform both technical and management tasks.

Other solutions have been developed for medium-scale and large-scale projects. All developed solutions are composed of processes supplemented with checklists, forms and templates.

\section{Project Management Processes Developed}

A process is defined as a set of related activities that transforms inputs into output elements. The central element of the proposed solution is a project management process guide. Three groups of project management processes have been developed:

- Project management process for small-scale projects

- Project management process for mid-scale projects

- Project management process for large-scale projects

The small-scale project management process was based on the Entry profile of the ISO/IEC 29110; the medium-scale project management process was based on the Basic profile of ISO/IEC 29110 and the large-scale project management process was improved and supplemented using the $\mathrm{PMBOK}^{\mathbb{B}}$ Guide. 


\section{5th Annual INCOSE International Symposium (IS2015) \\ Seattle, July 13-16, 2015}

\section{Checklists Developed}

Checklists are tools that can be very useful. They allow, among other things, to list the minimum steps to do when managing a project. Checklists may be useful tools for project managers for the following reason:

- They are a good way to explain or to remind, in a concise way, the tasks that a project manager must do;

- They identify the forms and the templates available for each project management task;

- They provide links to additional references;

- They guide the project manager in classifying the project management document produced during a project;

- They facilitate the evaluation of the implementation of the project management process.

As part of this project to improve management practices projects, five checklists were developed:

- Project management process of small-scale projects

- Project management process of medium-scale projects

- Project management process of large-scale projects

- Preparation of service offerings

- Preparation of detailed project planning

\section{Project Management Forms and Templates Developed}

Forms and templates were developed to guide project managers in the execution of management tasks and enable a consistency of results. They also serve to guide project managers unfamiliar with some project management practices.

\section{Testing Solutions Developed}

Testing solutions in the context of real project validated that the proposed solutions were consistent, feasible and complete. The small and medium processes and tools have been tested. The pilot projects consisted of running three different projects where project managers implemented the process and the associated tools.

Managers then evaluated the proposed processes, identified problems and potential improvements. The lessons learned sessions conducted at the end of the pilot projects have identified minor adjustments to the processes and tools.

\section{Deployment Strategy}

Once the final adjustments were made to the project management process and tools, a strategy was developed for the deployment of these solutions to all project managers of the division, i.e. about thirty persons. The strategy consisted of the following three components: communication, training and diffusion of the processes and their supporting documents.

The first phase was to inform project managers. In order to reduce questioning and to mitigate the negative impacts that 'unknown' can generate project changes, various means have been implemented to inform all managers. Here are some of them:

- Informative emails were sent;

- Articles were published in the monthly newsletter of the company; 


\section{5th Annual INCOSE International Symposium (IS2015) \\ Seattle, July 13-16, 2015}

- Informational messages have been added to the company intranet.

In addition, one-day training sessions have been prepared for project managers. The training allowed the project managers to learn the new processes and tools developed.

The second phase was used to distribute documents to all managers located in ten offices of the company in Canada. The most appropriate medium was the company's intranet. A section of the intranet, dedicated to project management, was created and served as a main access to project management documents such as project management process guides, checklists, forms and templates. This section of the intranet also contains information relevant to project management as links to websites, the identification of project management standards and other information such as projects management books.

\section{NEXT STEPS}

Since the utilization of ISO/IEC 29110 was very successful in the development project management processes, the recently published systems engineering ISO/IEC 29110, mainly based on ISO/IEC/IEEE 15288, will be used by the engineering division to redefine and improve its existing engineering process. This process will address the activities required from engineering requirements identification to final product delivery.

The Basic profile, as illustrated in Figure 5, as for the software engineering Basic profile which was used to develop the systems engineering Basic profile, is composed of two processes: a Project Management (PM) process and a System definition and Realization (SR) process.

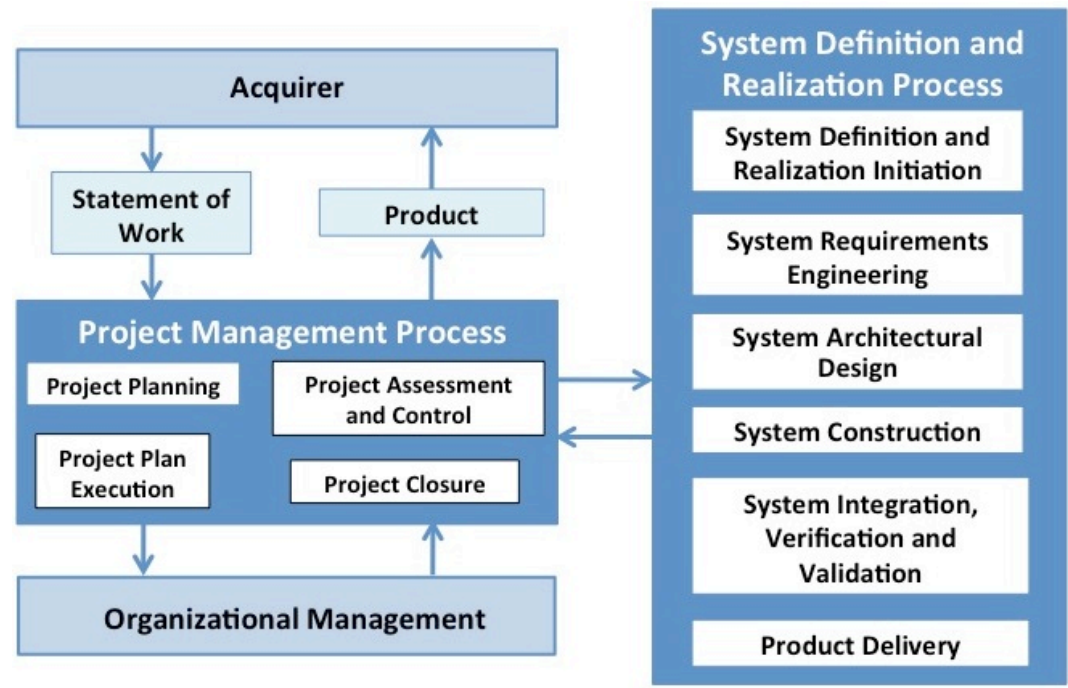

Figure 5 Processes and activities of the systems engineering Basic profile (Laporte 2014 c)

The ISO/IEC 29110 standards and guides for systems engineering are designed to work hand-inhand with the ones for software engineering. 


\section{5th Annual INCOSE International Symposium (IS2015) \\ Seattle, July 13-16, 2015}

\section{Conclusion}

ISO/IEC 29110 enabled a division of a large engineering consulting firm to develop project management processes for their small-scale and medium-scale projects that offered a structured approach to its project managers. The actions required by such processes are restricted to the most essential ones in order to limit the management effort per project.

The tools developed to support the project management processes proved very useful and helped the project managers rapidly integrate the knowledge required to execute the processes.

For the first time, the company has documented management processes for small-scale projects. Besides, some project managers have joined forces to promote project management practices within this engineering firm's division.

The improvement program was so successful that managers of the company's other divisions have shown an interest in learning this approach in order to implement it within their respective divisions. One division of the enterprise is now planning to review its process for the engineering activities.

Since the utilization of ISO/IEC 29110 was very successful in the development project management processes, the recently published systems engineering ISO/IEC 29110 Entry and Basic profiles will be used to redefine and improve the existing engineering process (ISO 2014, ISO 2015). This process will address the activities required from engineering requirements identification to final product delivery.

\section{Additional Information}

The following Web site provides more information, as well as articles by WG24 members and deployment packages for software and systems engineering:

http://profs.logti.etsmtl.ca/claporte/English/VSE/index.html

\section{References}

(Chevalier 2012) Chevalier, F., Programme d'amélioration des processus de gestion de projets adaptés à l'envergure des projets, École de technologie supérieure, Montréal (Québec), Canada, 2012.

(ISO 2005) ISO/IEC JTC1/SC7 N3288, New Work Item Proposal - Software Life Cycles for Very Small Enterprises, May 2005. http://www.jtc1-sc7.org/

(ISO 2010) Economic Benefits of Standards: Implementation Guide. Geneva, Switzerland: International Organization for Standardization, February 2010. http://www.standardsinfo.net/info/benefits/benefits_s1.html

(ISO 2011) ISO/IEC TR 29110-5-1-2:2011, Software Engineering - Lifecycle Profiles for Very Small Entities (VSEs) - Part 5-1-2: Management and engineering guide - Generic profile group: Basic profile, International Organization for Standardization/International Electrotechnical Commission: Geneva, Switzerland. Available at no cost from ISO at: 


\section{5th Annual INCOSE International Symposium (IS2015) \\ Seattle, July 13-16, 2015}

http://standards.iso.org/ittf/PubliclyAvailableStandards/c051153_ISO_IEC_TR_29110-51 2011.zip

(ISO 2012) ISO/IEC TR 29110-5-1-1:2012, Software Engineering - Lifecycle Profiles for Very Small Entities (VSEs) - Part 5-1-1: Management and engineering guide - Generic profile group: Entry profile, International Organization for Standardization/International Electrotechnical Commission: Geneva, Switzerland. Available in English at no cost from ISO

(http://standards.iso.org/ittf/PubliclyAvailableStandards/c060389_ISO_IEC_TR_29110-

5-1-1_2012(E).zip) and in French

(http://standards.iso.org/ittf/PubliclyAvailableStandards/c051153 ISO IEC TR 291105-1-2_2011(F).zip)

(ISO 2014) ISO/IEC TR 29110-5-6-2:2014 - Systems and software engineering - Lifecycle Profiles for Very Small Entities (VSEs) - Systems engineering - Management and engineering guide: Generic profile group: Basic profile, International Organization for Standardization/International Electrotechnical Commission: Geneva, Switzerland. Available in English at no cost from ISO

(http://standards.iso.org/ittf/PubliclyAvailableStandards/c063371_ISO IEC 29110-56_2_2014.zip) and in French (http://standards.iso.org/ittf/PubliclyAvailableStandards/index.html)

(ISO 2015) ISO/IEC TR 29110-5-6-1:2015- Systems and software engineering - Lifecycle Profiles for Very Small Entities (VSEs) - Systems engineering - Management and engineering guide: Generic profile group: Entry profile, International Organization for Standardization/International Electrotechnical Commission: Geneva, Switzerland. Available at no cost from ISO at:

http://standards.iso.org/ittf/PubliclyAvailableStandards/index.html

(Land 1997) Land, S. K., Results of the IEEE Survey of Software Engineering Standards Users.

Software Engineering Standards Symposium and Forum, 1997. Emerging International Standards. ISESS 97, Walnut Creek, CA, June 1-6, pp. $242-270$.

(Laporte 2013) Laporte, C.Y., Séguin, N., Villas Boas, G., Seizing the benefits of software and systems engineering standards, ISO Focus+, International Organization for Standardization, February 2013, pp 32-36.

http://www.iso.org/iso/home/news_index/iso_magazines/isofocusplus_index/isofocusplus 2013/isofocusplus 2013-02.htm

(Laporte 2014a) Laporte, C.Y., O'Connor, R., Systems and Software Engineering Standards for Very Small Entities - Implementation and Initial Results, QUATIC'2014, 9th International Conference on the Quality of Information and Communications Technology, Guimarães, Portugal, 23-26 September, 2014.

(Laporte 2014b) Laporte, C.Y., Houde, R., Marvin, J., Systems Engineering International Standards and Support Tools for Very Small Enterprises, Paper to be presented at the 24th Annual International Symposium of INCOSE (International Council on Systems Engineering), Las Vegas, US, June 30th-July 3, 2014.

(Moll 2013) Moll, R., Being prepared - A bird's eye view of SMEs and risk management, ISO Focus + , Geneva, Switzerland: International Organization for Standardization, February 2013.

(OECD 2005) SME and Entrepreneurship Outlook, 2005 Edition. Organization for Economic Co-Operation and Development, Paris, 2005. 


\section{5th Annual INCOSE International Symposium (IS2015) \\ Seattle, July 13-16, 2015}

(PMI 2013) PMI, A Guide to the Project Management Body of Knowledge (PMBO® Guide), Fifth edition. Project Management Institute, Newtown Square, PA, 2013.

(Porter 2008) Porter, M.E., On Competition, Updated and expanded, Boston, Mass, Harvard Business School Publication, Boston, 2008.

(Potter 2002) Potter, N., Sakry, M., Making Process Improvement Work. Addison-Wesley Pearson Education, 2002.

(SEI 2010) Software Engineering Institute. (2010). CMMI for Development, Version 1.3, Pittsburgh, PA: Carnegie Mellon University. CMU/SEI-2010-TR-033.

\section{Biography}

Dr. Claude Y. Laporte has been a professor since 2000 at the École de technologie supérieure (ÉTS), an 7,800-student engineering school, where he teaches software engineering. His research interests include software process improvement in small and very small enterprises, as well as software quality assurance. He has worked in defense and transportation enterprises for over 20 years. He received a Master's degree in Physics from the Université de Montréal, a Master's degree in Applied Sciences from the École Polytechnique de Montréal and a Ph.D. from the Université de Bretagne Occidentale (France). In addition, he was awarded an honorary doctorate by the Universidad de San Martin de Porres (Peru) in 2013. He is the Editor of ISO/IEC JTC1 SC7 Working Group 24, tasked to develop ISO/IEC 29110 life cycle standards and guides for Very Small Entities. He is the Co-chair of the INCOSE Systems Engineering for Very Small Entities WG. He is a member of INCOSE, IEEE, PMI and a member of the professional association of engineers of the Province of Québec (Ordre des ingénieurs du Québec). He is the co-author of two French books on software quality assurance published in 2011 by Hermes Science-Lavoisier and one English textbook, on the same topic, published by John Wiley and Sons in 2016.

Web site address: http://profs.etsmtl.ca/claporte/English/index.html

Frédéric Chevalier is an electrical engineer and project leader. He is the change agent of the improvement program that consisted in defining and implementing project management processes for an engineering company. He obtained a Master degree in Software engineering from the École de technologie supérieure in 2012. He is a member of the professional association of engineers of the Province of Québec (Ordre des ingénieurs du Québec) and of PMI. 